\title{
Is the public sector interpreting market ready for digital transformation?
}

\author{
Antonio Tejada Delgado
}

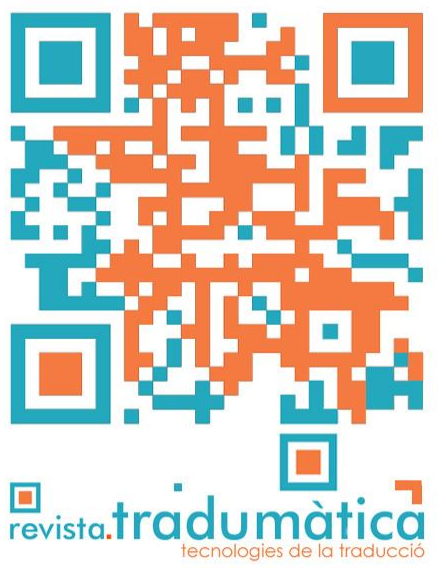

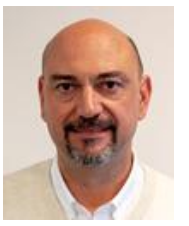

Antonio Tejada Delgado Managing Director at Capita Translation and Interpreting Ltd.

Antonio.Tejada@capita.com; ORCID:

0000-0003-4755-2569
Abstract

Interpreting global demand continues growing as we face large immigration trends worldwide and diversity is part of both the economic and political agenda. There are clear signs that transformation is coming and that new opportunities for disruption are opening, combined with a strong need from the administration to drive efficiency in all their services, and this includes the provision of interpreting to the increasingly diverse society. Services like Capita LiveLINK, using cloud-based workforces and highly efficient video and voice platforms with app-based delivery channels, have facilitated already large conversions of demand from on-premise to remote, thus delivering significant savings to the customer but also opportunities for our interpreters. The interpreting stakeholders must join forces to drive the digital transformation as an industry and not to just react to external forces.

Keywords: remote interpreting; public sector market; digital transformation; Capita LiveLINK; video interpreting.

Resum

La demanda global d'interpretació creix a mesura que ens enfrontem a grans moviments migratoris arreu del món així com a una escena econòmica i política molt diversa. Existeixen clars signes d'una transformació que obre noves oportunitats de disrupció, juntament amb una forta necessitat d'impulsar per part de l'administració l'eficiència en tots els seus serveis, cosa que inclou proporcionar interpretació a una societat cada vegada més diversa. Els serveis com Capita Livelink, on la plantilla utilitza tecnologia en el núvol i plataformes de vídeo i veu altament eficients, amb canals de lliurament basades en aplicacions, ja porten a terme grans conversions d'una demanda local a una de remota, cosa que es tradueix en un important estalvi per al client, així com en noves oportunitats per als nostres intèrprets. Els diferents agents del món de la interpretació han d'unir les seves forces per impulsar com a indústria la transformació digital i no només reaccionar davant forces externes.

Paraules clau: interpretació remota; mercat del sector públic; transformación digital; Capita LiveLINK; viedointerpretació. 
Resumen

La demanda global de interpretación crece a medida que nos enfrentamos a grandes movimientos migratorios en todo el mundo así como a una escena económica y política muy diversa. Existen claros signos de una transformación que abre nuevas oportunidades de disrupción, junto con una fuerte necesidad de impulsar por parte de la administración la eficiencia en todos sus servicios, cosa que incluye proporcionar interpretación a una sociedad cada vez más diversa. Los servicios como Capita LiveLINK, cuya plantilla utiliza tecnología en la nube y plataformas de vídeo y voz altamente eficientes, con canales de entrega basados en aplicaciones, ya llevan a cabo grandes conversiones de una demanda local a una remota, lo que supone un importante ahorro para el cliente, así como nuevas oportunidades para nuestros intérpretes. Los diferentes agentes del mundo de la interpretación deben unir sus fuerzas para impulsar como industria la transformación digital y no sólo reaccionar ante fuerzas externas.

Palabras clave: interpretación remota; mercado del sector público; transformación digital; Capita LiveLINK; videointerpretación.

\section{Is the public sector interpreting market ready for digital transformation?}

Interpreting global demand continues growing as we face large immigration trends worldwide and diversity is part of both the economic and political agenda. Only in the UK, more than 300 languages are spoken today and in some boroughs, such as Tower Hamlets in London, over $30 \%$ of the population use a language other than English as their main language.

Interpreting represents $16.25 \%$ of total global spending on language services which translates to nearly $\$ 7.5 \mathrm{bn}$, of which on-site interpreting accounts for the largest portion at around \$3.5bn (Source: Language Services Market Report 2019 - Common Sense Advisory). In the UK alone the Ministry of Justice spends over $£ 15$ million per year, which illustrates the fact that the UK interpreting market is driven largely by public spending. Revenue is primarily generated by government contracts and with a service delivery model implying high levels of logistics due to the long-standing requirement for a face to face service. This makes it more difficult for companies in this sector to develop further afield, especially to drive international expansion, while it also poses serious challenges to the bottom line, as we have seen in recent years in the UK with several interpreting companies filing for bankruptcy.

These alone should be reasons enough for the interpreting ecosystem (suppliers, buyers and end users) to push for adopting technology to better serve this demand, and as the prospect of the market adopting disruptive innovation is almost a given, as we have seen in the translation sector. The reality is that we have been experiencing a genuine digital transformation in a service in the last five years alone which has historically been considered non-digital.

As part of the strategic analysis we carried out at Capita Translation and Interpreting (one of the largest interpreting services providers in the UK) to drive digital transformation in our services, we discovered the following:

Technology was primarily used to drive service delivery efficiency. Interpreting Management Systems were used by most large suppliers and we have all developed or 
purchased tools that help us to manage large volumes of work regarding geographical and qualifications segmentations.

Telephone interpreting was a fallback service when on-site was not feasible or too onerous. The technology behind this service is, in many cases, obsolete and uses traditional call routing telephone systems.

Interpreters were not necessarily considered tech-savvy and so not classed as a "digital workforce". This means that using technology to provide these services would also imply a transformation of the professionals behind it.

Revenue models were built around on-premise interpreting, which means that any push to introduce technology would have a significant impact on the results of the incumbent suppliers. Replacing a 2-hour interpreter appointment with a 15-minute video call can reduce charges to the client by $75 \%$.

Specific legislation and infrastructure availability in the public services sector posed challenges. For example, some services, like Police interpreting, will be regulated to protect the rights of the person being questioned.

We started to see a large growth in interpreting applications/platforms driven by technology disruptors.

- The requirements set out by public sector contracts limited the opportunity to deploy technology.

These factors have prevented technology to take a more prominent role on the UK interpreting market and follow more advanced models like the US healthcare system where companies like Stratus have managed to drive high growth on the back of transforming the services from on-premise to video.

There is little doubt that disruptive technology is becoming more and more readily available. Investment firms and language suppliers like us are presently providing back up for over 50 projects to deliver digital solutions which are focused on either automating scheduling processes, the channels used to provide the service (remote interpreting) or actually automating the service itself using machine interpreting.

Since we launched our remote interpreting platform, Capita LiveLINK, we have converted $25 \%$ of our services from on-premise to remote, because we are integrating our existing on-site professionals into the platform and transforming the delivery model rather than just implementing a piece of technology. Even interpreting units in international organizations, like the European Commission's Directorate General for Interpretation (DG $\mathrm{SCIC}$ ), have started to consider video remote interpreting (VRI). After testing four interpreting platforms - Interactio, Interprefy, Kudo, and VoiceBoxer - the DG SCIC recently concluded that such platforms can be used to provide interpreting. And in May 2019, Google Al announced a new experimental system, called Translatortron, which is the first end-to-end, speech-to-speech solution that can directly translate speech from one language into speech into another.

\section{What needs to change to digitally transform the public sector interpreting market?}


As has been happening in the translation market for many years with the adoption of Machine Translation, the digital transformation of the interpreting market is an ecosystem shift that requires all elements to adapt. As in any ecosystem, if elements don't adapt this presents a large opportunity for an external element to disrupt and shift the existing balances.

\subsection{Incumbent suppliers (LSPS)}

We must be the catalysts of transformation because we play an intermediary role between market demand, technology and the interpreter. Language providers have a responsibility to not only find the most efficient and sustainable answer to the increasing demand, but also to look at improving the working conditions of our interpreters and helping to develop their careers.

The first change we must embrace is to adopt a different financial model and be prepared to see our revenue generation shifting from on-site to remote. In the short term this will initially impact on our overall results as we will be passing on the efficiency of using technology to our customers, but in the long run this will mean higher growth, as companies in the US like Stratus have proven over the past four years.

Language Service providers will also need to change the profile of the services they offer to their customers, as we must act as agents of transformation and therefore be more consultative in our approach to delivering the service, drive adopting technology and challenge our customers to change.

Our service delivery models will also be impacted by this transformation, so we need to work with our interpreters to make them more digitally savvy and support them through a journey that will certainly present challenges, but also great rewards. We envisage an interpreter who will be able to enter multiple markets with fewer geographical barriers (travel will be reduced) and capable of leveraging their expertise, which will allow for a more equal opportunity market (for example, breaking disability barriers). It will largely depend on the language providers to drive these benefits and not simply see new models as a more efficient delivery mechanism, but rather as a real disruption.

We started this process at Capita Translation and Interpreting two years ago with the introduction of LiveLINK, and we have seen over 400 of our traditionally on-premise interpreters now become part of our remote interpreting platform and combine face to face with voice and video interpreting.

This has not only improved our service to our public sector customers with response times of 15 seconds and higher satisfaction rates and lower costs, but also provided a better work life balance for our interpreters and the opportunity to develop their careers.

\subsection{Interpreters}

Interpreters are the core of our ecosystem and the digital transformation that needs to take place in the interpreting market cannot happen without their engagement and support, which will depend on how we structure the change to make sure they benefit 
from the outset. This transformation needs to deliver flexibility, fair reward, career development opportunity and professional pride.

We have proven this is achievable when embracing our own digital journey, as we have developed a model that has engaged our existing interpreters and provided them with a flexible working environment that allows them to continue offering traditional onpremise services and at the same time being available for video or voice.

Our interpreters involved in LiveLINK have increased their overall earnings from us by $12 \%$ on average, as they can better utilise their time and increase their productivity. We have interpreters who before were typically constrained to a geographical area, but who now are transferring their expertise to other regions in the UK, and some are even working with our customers in the US.

It is also important to mention here the role of universities and certification bodies, as there is an opportunity and a need to ensure interpreters are trained and qualifications are available, including the new delivery channels such as video and also telephone.

\subsection{Customers}

Particularly within the public sector, there is no doubt about the immediate benefits that a digital transformation towards technology driven interpreting services will bring. Some of these benefits are not directly visible to the customer, as they are looking more at scheduling and sourcing efficiencies driven by Interpreting Management Systems and workforce management applications. Nevertheless, committing to very demanding service levels, such as 2-hour delivery of on-premise interpreters with specific vetting requirements, will not be possible without a high level of automation.

The public sector (in the UK particularly the NHS, but also other public services such as the court system) is looking to make a major move from on-premise interpreting requirements towards remote interpreting. The introduction of remote interpreting platforms that can triage multiple service requirements will be the key, but there is work to do by the owners of government contracts prior to reaching this:

- There needs to be clarity on the requirements that can be fulfilled using technology and this must be reflected in the contract conditions.

- Coordination with other digital transformation programmes, because governments are looking at modernising their infrastructure.

- Cultural change to promote remote services as a quality alternative.

- Dialogue leaders to engage all stakeholders in the ecosystem and act as a transformational driving force.

- Not fall on an only price driven change model.

\subsection{Technology suppliers}


Although we are seeing a high number of new service providers with a high technology component looking to disrupt the market, there are not many purely technology suppliers developing supplier agnostic solutions, looking at just delivering a software as a service platform that can be utilised by language service providers. As the big price is on providing the interpreting service itself, most of the investment is dedicated to proprietary solutions trying to displace the existing suppliers rather than enabling transformation.

Traditional LSPs can find multiple options to transform their translation workflows or service delivery models from independent technology suppliers, and even those who also provide translation services, such as SDL, have managed to draw a clear line between both. While this is not normally the case in interpreting, the LSP is almost asked to give up the transformation process to the new technology supplier who also wants to own the service.

\section{Conclusion}

There is an unrefutably increasing interest in interpreting as a market, as there are clear signs that a transformation is coming and that new opportunities for disruption are opening up, combined with a strong need by public administrations to drive efficiency in all their services. This of course includes the provision of interpreting to an increasingly diverse society.

The US market, and particularly the healthcare system, has proven that video interpreting and the combination of multiple services can be successful and improve the services on offer. It has also shown us that it can be profitable with companies like Stratus.

Services like Capita LiveLINK, using cloud-based workforces and highly efficient video and voice platforms with app-based delivery channels, have already facilitated large conversions of demand from on-premise to remote, delivering significant savings to the customer but also opportunities for our interpreters.

We are just not seeing it as an industry driven digital transformation and this is where the risk is for all of us in the ecosystem lies. If we take the example of the traditional taxi sector, we have seen how a slow reaction by the established stakeholders caused them to miss the opportunity to drive the service transformation and are now having to play catch up. Similar to what the translation market embraced via organisations like TAUS in driving the adoption of Machine translation, the interpreting stakeholders must join forces to drive digital transformation as an industry and not to just react to external forces. 